\title{
Gastritis due to spiral shaped bacteria other than Helicobacter pylori: clinical, histological, and ultrastructural findings
}

Institute of Pathology, Municipal Hospital, Landshut, West Germany K L Heilmann

Institute of Pathology, University of Düsseldorf, West Germany F Borchard

Correspondence to: Prof DrF Borchard, Zentrum fuer Pathologie der HeinrichHeine-Universität, Moorenstrasse 5, 4000 Duesseldorf 1 , FRG. Professor Heilmann died after this paper was accepted.

Accepted for publication 12 March 1990

\author{
K L Heilmann, F Borchard
}

\begin{abstract}
An intensive histological search for Helicobacter pylori in gastric biopsy specimens has led to the detection of other spiral shaped bacteria in the human gastric mucosa. The clinical and morphological findings of 39 cases $(0.25 \%$ of all gastric biopsies performed in the observation period) are reported for 34 patients $(87 \cdot 2 \%)$ complaining of upper abdominal discomfort. Five patients $(12 \cdot 8 \%)$ had chronic gastritis and $34(87 \cdot 2 \%)$ chronic active gastritis. The organisms were seen by light microscopy deep in the gastric foveolae and intracellularly. The scanning and transmission electron microscopic findings show bacteria which invade and damage gastric mucosal cells. These organisms are similar to the spiral shaped bacteria found in the stomachs of cats and dogs and non-human primates. In eight patients organisms were not detected after four weeks of treatment with bismuth salts. The disappearance of the organisms coincided with resolution of the chronic active gastritis and the symptoms.
\end{abstract}

The ecological niche in the gastric mucosa is probably able to harbour other bacteria besides the well known Helicobacter pylori. These 'other' organisms share some properties with $H$ pylori. They are helical in shape, have flagellae, produce urease, and their presence is associated with a chronic active type $B$ gastritis. ${ }^{1-7}$

We present the clinical, morphological, and ultrastructural findings for 39 patients infected with those spiral bacteria.

\section{Patients and methods}

Of the 39 patients 24 were men, mean age $54 \cdot 2$ years (range 20-76), and 15 were women, mean age 50.6 years (range 19-79) living in different parts of Germany. Thirty four patients $(87 \cdot 2 \%)$ complained of dyspeptic symptoms such as postprandial discomfort, epigastric pain, vomiting, heartburn, and dysphagia, lasting from one month to two years. Four patients were asymptomatic and one patient had diarrhoea due to pancreatic insufficiency. The endoscopic appearances in the antral and corpus mucosa were normal. There was no duodenal or gastric ulcer or tumorous lesion at the time of biopsy. A biopsy urease test was performed in five patients and was positive after 20 minutes.

In our institution all gastric biopsy particles are fixed in $4 \%$ neutral formalin, embedded in paraplast, and cut in $3 \mu \mathrm{m}$ thick sections. The slides are stained routinely by an alcohol haema- toxylin and eosin solution. Besides studying the biopsy specimens for morphological changes under low and high power magnification, all slides were screened by one observer (KLH) under oil for the presence of bacterial organisms. By this method it is possible to identify $H$ pylor $i$ without special stains. ${ }^{8}$ After identification of spiral shaped bacteria in the specimens, they were stained with Gram, Giemsa, Steiner, and Whartin-Starry silver stains. Tissue for electron microscopy was fixed in buffered glutaraldehyde and postfixed in OsO4. Semi-thin sections were screened for spiral shaped bacteria and selected ultrathin sections further analysed in a Zeiss-EM 109 electron microscope. For scanning electron microscopy, formalin fixed biopsy specimens were postfixed in a similar way, dried with the critical point method, and coated with gold. The specimens were viewed by the Philips SEM 515 scanning electron microscope.

\section{Results}

INCIDENCE AND LOCATION OF BACTERIA

The 39 cases represent $0 \cdot 25 \%$ of all antral biopsies performed in the observation period $(n=15180)$. Spiral shaped bacteria were observed in the antrum in all patients and in five of 25 patients in the fundus. Chronic active type $B$ gastritis was present in 34 patients in the antral mucosa. In four patients there was only a lymphoplasmacytic infiltrate. As in $H$ pylori associated gastritis the granulocytes were fre-

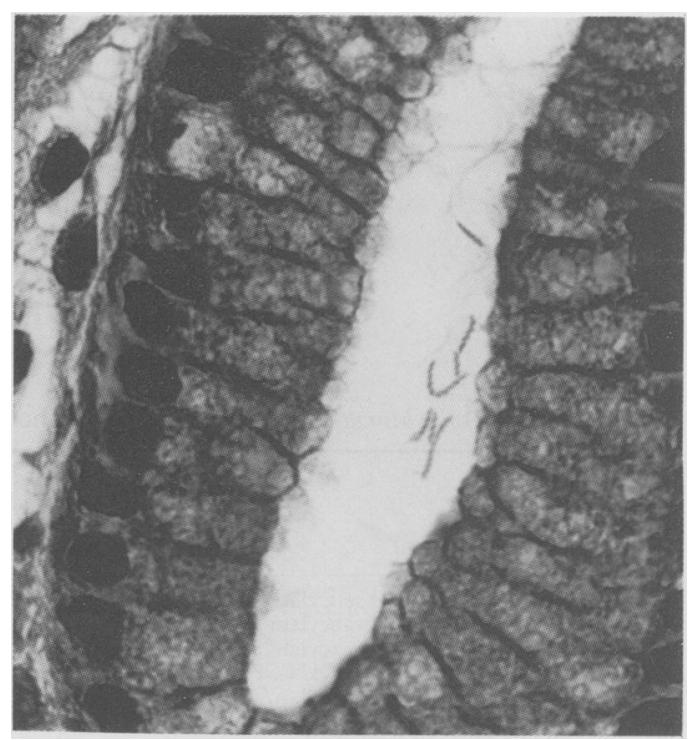

Figure 1: Gastrospirillum hominis in a gastric pit in the antral musoca. (Haematoxylin and eosin. Original magnification $\times 800$.) 


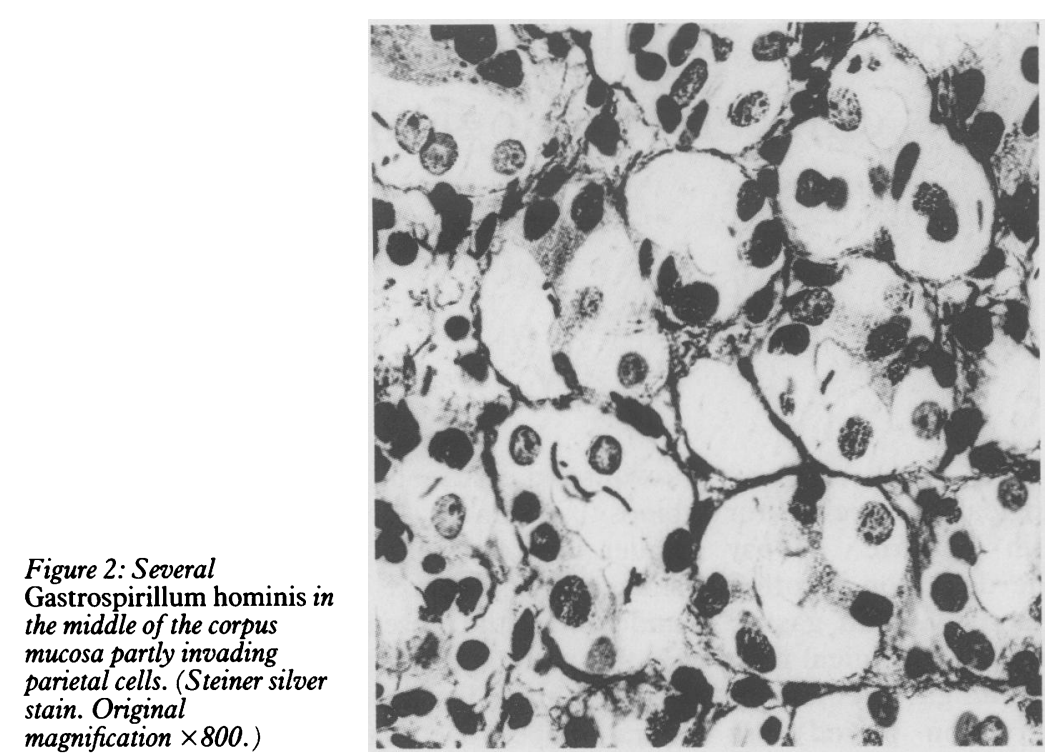

quently located in the superficial epithelial cells. Twenty three of the 25 fundic specimens showed mild inactive gastritis and the remaining two cases chronic active gastritis.

The organisms are about $7-10 \mu \mathrm{m}$ long and have four to six spirals. They may occur as single organisms or in small groups located underneath the mucous layer, above the surface cells, and deep in the lumen of the foveolae (Fig 1). They are generally less numerous than $H$ pylori and never cover the entire surface. There is no adherence to the surface cells and no special relation to the intercellular tight junctions. In the corpus mucosa spiral shaped bacteria can be identified by the silver stain deep in the mucosa, in the lumen of the glands, and even in parietal cells (Fig 2). In one patient with severe chronic active gastritis $H$ pylori could be identified in addition to the spiral shaped bacteria. The organisms are weakly stained by haematoxylin and eosin, are Gram negative, and display their structural characteristics well in the Giemsa, Steiner, and Whartin-Starry silver stain.

\section{SERIAL STUDIES}

One patient was biopsied 10 years before the last biopsy was done. In that earlier biopsy identical organisms could be identified. There was a mild chronic active gastritis and a history of duodenal ulcer. Another patient was biopsied four years before and showed retrospectively spiral shaped bacteria associated with chronic active gastritis and a gastric ulcer. Eight patients were treated with bismuth subsalicylate and were free of symptoms four weeks after the initial diagnosis. Biopsies in these cases, performed between eight and 16 weeks, showed only scattered lymphocytes and a few plasma cells in the lamina propria, but no granulocytes and no colonisation by spiral shaped bacteria (Table).

\section{TRANSMISSION ELECTRON MICROSCOPY}

In two patients ultrastructural studies were performed. The spiral shaped bacteria were seen in biopsy specimens of the antral mucosa (Fig 3) and corpus mucosa (Fig 4). The diameter may vary: it usually averages $0.65 \mu \mathrm{m}$, but the maximum width was $0.9 \mu \mathrm{m}$. The amplitude is about $0.8 \mu \mathrm{m}$. Usually up to four spirals are in the plane of section; therefore, the actual length could not be determined by this method. The ends are partly pointed, partly blunt. At the blunt end of the organisms an insertion complex is visible with up to 12 flagellae (Figs 3 and 4 (inserts)). In the region of the insertions the bacterial cell wall shows undulation. The flagellae have swollen ends. Their variable form, with a partial parallel course and partial cord-like twisting, suggest the motility of these organelles. The sickle shaped area next to the insertion complex (Figs 3 and 4) shows less densely packed granular material than elsewhere in the bacterium, but also dense granular structure may occur here. The cell wall is trilaminar (Fig 3). There are no axial filaments and no periplasmic fibres as in Spirochaetales. The bacteria were seen on the surface of antral and corpus mucosa, below the mucus, sometimes in close contact to the membranes of surface mucous cells or antral mucopeptic cells without a preference for tight junctions. At the point of contact degenerative changes of the cell membrane and the microvilli become apparent (Fig 5). The microvilli show kinking and partial destruction. In the lower mucosa of the corpus the spiral shaped bacteria invade the canaliculi of parietal cells where as many as five can be seen, without obvious damage to their host cells. Bacteria, however, also invade the parietal cells, causing signs of cellular damage such as mitochondrial swelling (Fig 4). In the lower mucosa the bacteria invade mucopeptic cells and rarely endocrine cells. The infected cells react with swelling of the mitochondria, the formation of cytoplasmic empty vacuoles around the bacteria, and microvesicular disintegration of organelles, probably partly of lysosomal origin. Once disintegration of a bacterium was seen.
Effect of treatment with bismuth salts on Gastrospirillum hominis and the cellular infiltrate

\begin{tabular}{|c|c|c|c|c|c|c|c|c|c|}
\hline \multicolumn{2}{|l|}{ Patients } & \multirow[b]{2}{*}{ Treatment } & \multicolumn{2}{|c|}{$G$ hominis } & \multicolumn{2}{|c|}{ Granulocytes } & \multicolumn{2}{|c|}{$\begin{array}{l}\text { Lymphocytes/ } \\
\text { plasma cells }\end{array}$} & \multirow{2}{*}{$\begin{array}{l}\text { Interva } \\
\text { (days) }\end{array}$} \\
\hline Age (years) & Sex & & $B$ & $A$ & $B$ & $A$ & $B$ & $A$ & \\
\hline 28 & F & Bismuth subsalicylate/28 & + & - & ++ & - & + & + & 55 \\
\hline 41 & $\mathrm{~F}$ & Bismuth subsalicylate/28 & + & - & ++ & - & ++ & + & 45 \\
\hline 50 & $\mathbf{F}$ & Bismuth subsalicylate/28 & + & - & + & - & + & + & 138 \\
\hline 21 & $\mathbf{M}$ & Bismuth subsalicylate/28 & + & - & + & - & + & + & 30 \\
\hline 26 & $\mathbf{M}$ & Bismuth subsalicylate/28 & + & - & ++ & - & ++ & + & 30 \\
\hline 50 & $\mathbf{M}$ & Bismuth subsalicylate/28 & + & - & ++ & - & ++ & + & 50 \\
\hline 52 & $\mathbf{M}$ & Bismuth subsalicylate/28 & + & - & ++ & - & ++ & - & 79 \\
\hline 60 & $\mathbf{M}$ & Bismuth subsalicylate/28 & + & - & ++ & - & ++ & + & 35 \\
\hline
\end{tabular}

$\mathrm{B}=$ before treatment $\mathrm{A}=$ after treatment.
SCANNING ELECTRON MICROSCOPY

The organisms were aggregated in small clusters of 3-10 bacteria, some without any contact, partly lying parallel and close to each other (Fig 6). While most of the organisms were straight, bent forms were also noted. The bacteria have an average length of $6 \cdot 17 \mu \mathrm{m}$ (range $4 \cdot 8-6.7 \mu \mathrm{m}$ ) and a thickness of about $1 \mu \mathrm{m}$.

\section{Discussion}

The identification of spiral bacterial organisms 


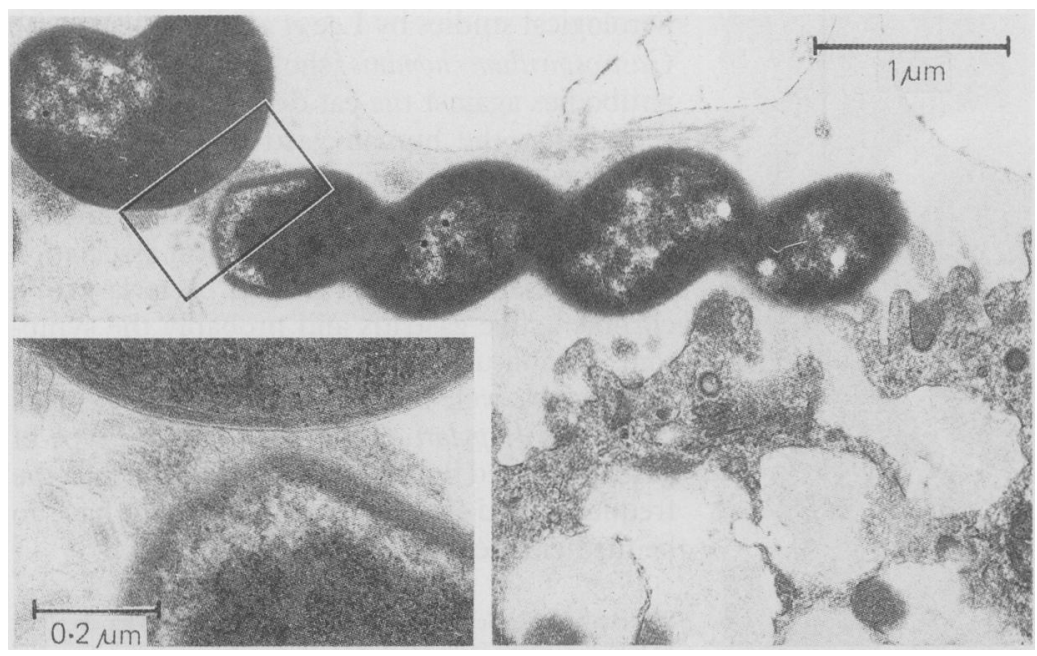

Figure 3: Gastrospirillum hominis lying on the surface of a mucopeptic cell. Degeneration of microvilli. (Transmission electron microscope. Original magnification $\times 32000$.) Filaments partly attached to the 'end' of another bacterium. (Box $\times 110000$ original magnification.)

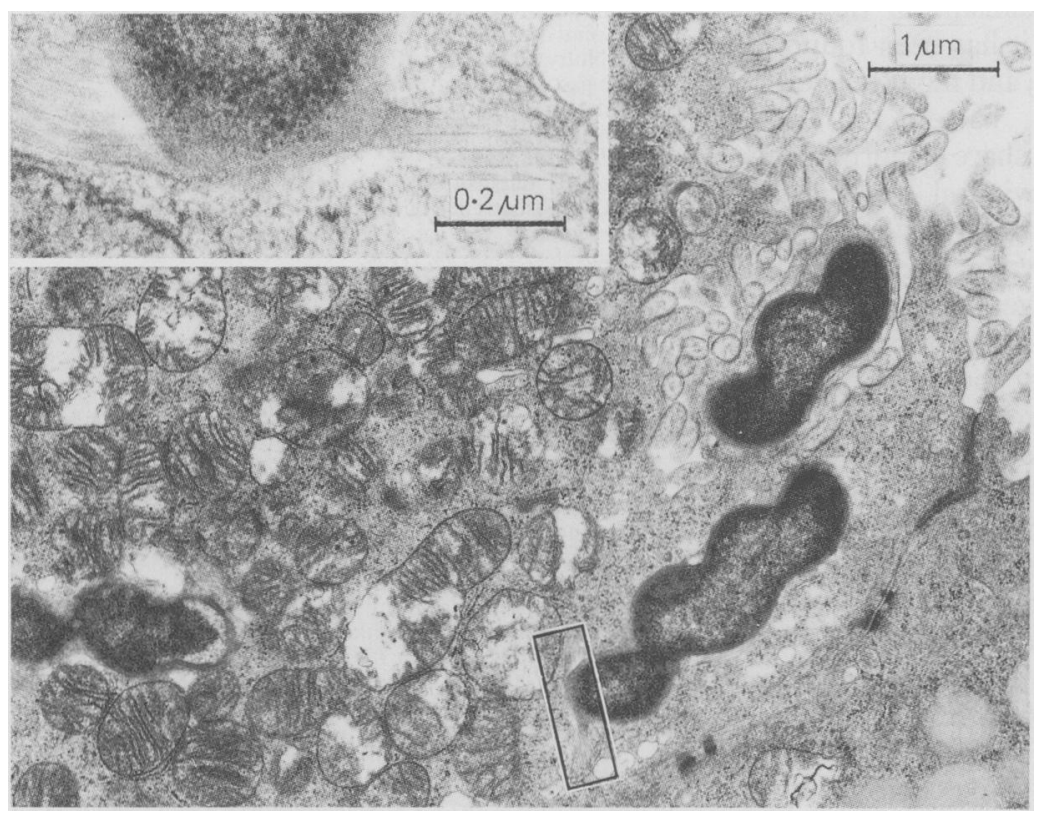

Figure 4: Three bacteria within a parietal cell: while one is still in the canalicular system, the other bacteria have invaded the cytoplasm causing degeneration-like mitochondrial swelling. (Transmission electron microscope. Original magnification $\times 20000$.) The inset shows twisting of bacterial filaments. (Box $\times 110000$ original magnification. $)$

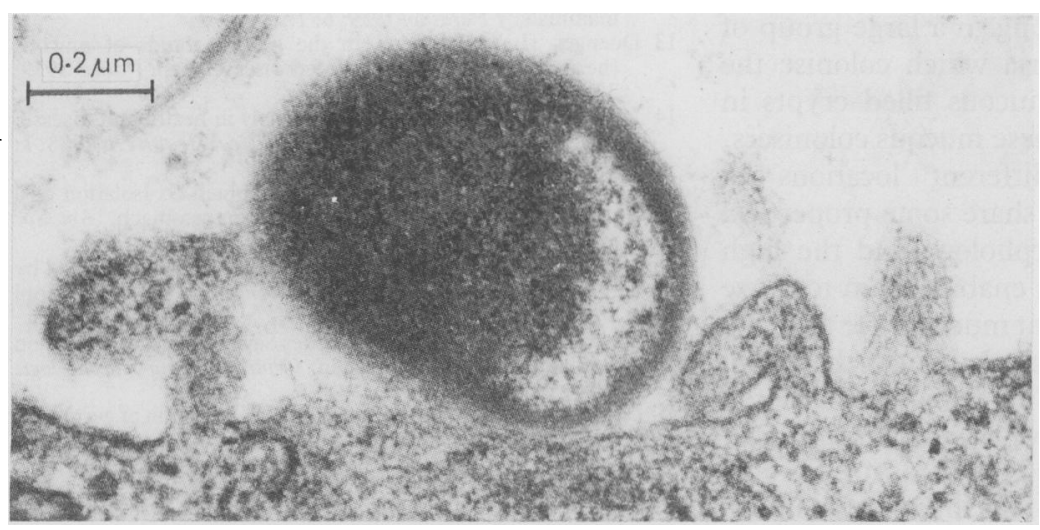

Figure 5: Attachment of a bacterial 'end' to the cytoplasmic surface with kinking of microvilli. (Transmission electron microscope. Original magnification $\times 100000$.

other than $H$ pylori in the human gastric mucosa associated clinically with the symptoms of nonulcer dyspepsia and morphologically with an active chronic gastritis suggests that $H$ pylori is not the only bacterial organism causing active chronic gastritis. It was proposed that these spiral organisms should be called 'Gastrospirillum hominis." Until now, the colonisation of the human gastric mucosa by Gastrospirillum hominis seems to be a rare event. We found 39 cases among 15180 antral biopsies - that is, roughly $0 \cdot 25 \%$. This is about the same incidence as the $0.36 \%$ reported from England ${ }^{12}$ and $0.3 \%$ from New Zealand, ${ }^{4}$ whereas the $0.6 \%$ reported from France exceeds these numbers. An intensive search for these organisms could probably show many more cases since the commonly used Whartin-Starry stain impregnates the organisms irregularly so that they may be falsely interpreted as $H$ pylori. As we and others could show that at least some of the organisms seem to produce urease, ${ }^{56}$ patients with Gastrospirillum hominis and a positive urease test could be falsely diagnosed as having an $H$ pylori infection without further histological studies. Since all attempts at culture have been unsuccessful until now, the diagnosis of this bacterial infection relies on a careful histological examination of the gastric biopsy specimens, either under high power or oil in haematoxylin and eosin, Gram, or Giemsa stained sections.

The distribution of the spiral shaped bacteria in the human gastric mucosa differs from that seen in $H$ pylori infection. Whereas they may be observed above the surface cells in the mucous layer, they appear more commonly deeply within the gastric pits. In contrast to light microscopy the spiral shaped bacteria ultrastructurally sometimes seem to be attached to the membranes of the surface cells with a possible effect on the membrane structures. There is, however, no attachment or penetration of the intercellular tight junctions as is seen in $H$ pylori colonisation. ${ }^{9}$ In contrast to the behaviour of $H$ pylori, the spiral shaped bacteria obviously cannot only damage cell membranes but penetrate them as well. We found the organisms intracellularly in mucous and endocrine cells in the antral mucosa as well as in the parietal cells in the fundic mucosa.

Similar to the other reported cases we could also prove that infection with spiral shaped bacteria is almost always associated with an active chronic gastritis generally less severe than in $H$ pylori infection. There was one case in which $H$ pylori and the spiral shaped organisms could be identified together, as was reported by the French group. ${ }^{7}$ This patient had a more severe chronic active gastritis. After treatment with bismuth salts, Gastrospirillum hominis could no longer be found, while $H$ pylori persisted. Gastrospirillum hominis infection is not necessarily temporary, but can persist for a long time, maintaining chronic active gastritis, as the two cases prove, where it was found 10 and five years before the last biopsy. There are several points which favour the aetiopathogenetic importance of Gastrospirillum hominis in inducing and maintaining gastritis in the human stomach: (a) The presence of the organisms is always associated with gastritis. (b) The suppression of Gastrospirillum hominis coincides with the disappearance of the gastritic changes.

Similar to the hitherto unresolved problem of source and spread of $H$ pylori infection, the origin of the spiral shaped bacteria is still a 


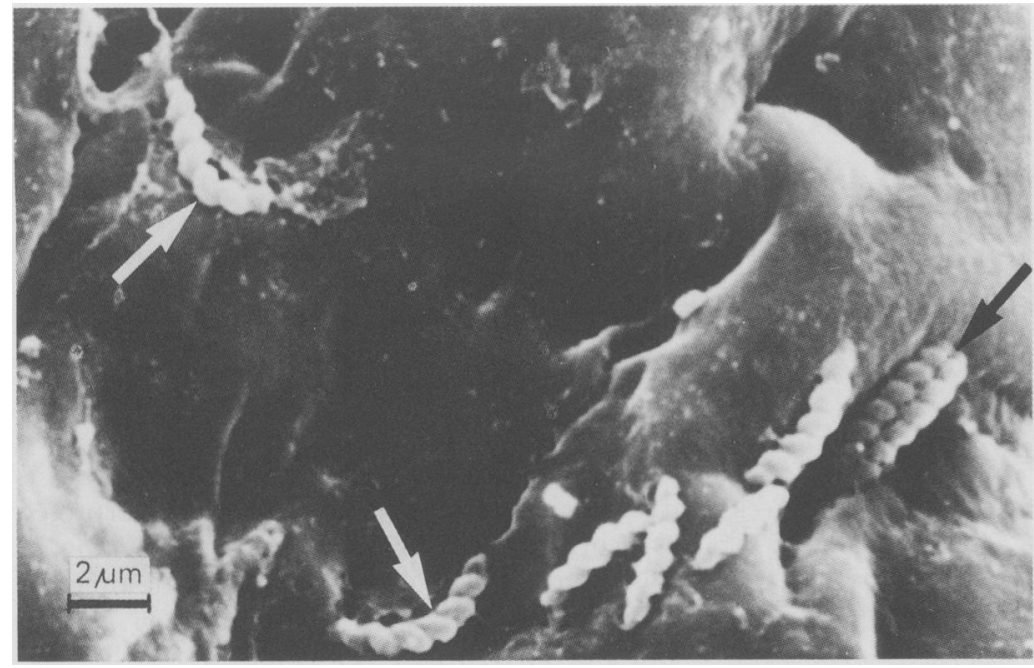

Figure 6: Gastrospirillum hominis on the mucosal surface of the gastric body; most are straight, $a$ few are bent (white arrows), and some lie parallel, close to each other (black arrow). (Scanning electron microscope. Original magnification $\times 8000$.

matter for discussion. Since Bizzozero ${ }^{10}$ described spiral shaped organisms in the gastric mucosa of dogs in 1893, it has been found that nearly all adult dogs, cats, and monkeys harbour similar spiral shaped bacteria. ${ }^{11-14}$ These organisms not only share morphological features, but also behavioural and adaptive features, with the spiral shaped bacteria found in human stomachs. As shown by Lee and Hazell, ${ }^{14}$ they are about the same size, the same characteristic shape, have a similar insertion complex, and have flagellae at their blunt ends. The organisms found in cats are able to produce urease. Particularly ultrastructurally, they are clearly different from the recently described urease positive CS1 organisms. As recently shown, there are at least two different spiral shaped organisms in the cat stomach: $(i)$ one that can be cultured and displays periplasmic fibres ('Helicobacter felis' 1 ) and (ii) another which is ultrastructurally very similar to Gastrospirillum hominis. ${ }^{16}$

As seen in humans, spiral organisms in animals also have the ability to penetrate mucous and parietal cells. ${ }^{10141617}$ But in the animal stomach the presence of those organisms is not always associated with gastritis, though Lee $e t$ al were able to induce gastritis in germ free mice with these organisms. ${ }^{18}$ It seems that these spiral organisms obviously belong to a large group of mucosa associated bacteria which colonise the mucous layer and the mucous filled crypts in most animal species. ${ }^{19}$ These mucous colonisers, though different at different locations in different animal species, share some properties, including the spiral morphology and the high degree of mobility which enables them to move in the viscous environment much better than the common rod shaped bacteria. Since the spiral shaped bacteria found in humans share the morphology and the adaptive mechanisms of cat and probably dog derived organisms it is feasible to assume that the presence of these organisms in human gastric mucosa is the consequence of an infection with these animal derived bacteria.
Serological studies by Lee $e t a l^{20}$ in patients with Gastrospirillum hominis showed cross reacting antibodies against the cat derived organisms. It seems that the human gastric mucosa always reacts with an inflammatory response to the infection with these animal derived mucosa associated organisms. There is a clear association of the presence of spiral shaped bacteria with a chronic active gastritis and probably the symptoms of non-ulcer dyspepsia in humans. Thus, besides the well recognised infectious gastritis caused by $H$ pylori, there exists another type of gastritis caused by animal derived organisms, the frequency and the importance of which have to be further elucidated.

We thank Mrs U Geusenhainer and Mrs S Schneeloch for excellen technical assistance in TEM and SEM; Mrs M Stoica and Mrs $M$ Schmidt for light microscopical stains; and Mrs E Preisser for preparing the manuscript.

KLH dedicated this paper with gratitude to Professor Dr J R Siewert, Munich.

1 Dent JC, McNulty CAM, Uff JS, Wilkinson SP, Gear MWL. Spiral organisms in the gastric antrum. Lancet 1987; ii: 96.

2 McNulty CAM, Dent JC, Curry A, et al. New spiral bacterium in gastric mucosa. 7 Clin Pathol 1989; 42: 585-91.

3 Heilmann KL. Spirochätenähnliche Organismen in der menschlichen Magenschleimhaut. Dtsch Med Wochenschr 1988; 113: 1298-9.

4 Dye KR, Marshall BJ, Frierson HF, Guerrant RL, McCallum RW. Gastritis in a human due to infection with an organism resembling the cat gastric spirillum [Abstract]. Gastroresembling the cat gastric

5 Morris A, Rafiq AM. Thomsen L, Vanderwel M, Hollis B Tightly spiral shaped bacteria in the human gastric antrum are they urease positive? First Meeting of the European Campylobacter pylori Study Group. Bordeaux. Amsterdam Excerpta Medica, 1988: 40.

6 Morris A, Ali MR, Thomsen L, Vanderwel M. Tightly spira shaped bacteria in gastric antrum: are they urease positive? $\mathcal{F}$ Clin Pathol 1989; 42: 216-9.

7 Morvan J, Vialette G, Lamouliatte $\mathrm{H}$, et al. Spiral bacteria different from Campylobacter pylori observed in human stomach tissue. First Meeting of the European Campylobacter stomach tissue. First Meeting of the European Campylobacter pylori Study Grow

8 Heilmann KL, Nowottny U. Histologischer Nachweis von CLO (Campylobacter like organisms) in Magenbiopsien Disch Med Wochenschr 1987; 112: 861-2.

9 Hazell SL, Lee A, Brady L, Hennesy W. Campylobacter pyloridis and gastritis: association with intercellular space and adaptation to an environment of mucus as important factors in colonization of the gastric epithelium. F Infect $D$ is 1986; 153: 658-63.

10 Bizzozero G. Über die schlauchförmigen Drüsen des MagenDarm-Kanals und die Beziehungen ihres Epithels zu dem Oberflächenepithel der Schleimhaut. Arch Mikr Anat 1893; 42: 82 .

11 Weber AF, Hase O, Sautter JH. Some observations concerning the presence of spirilla in the fundic glands of dogs and cats. Am F Vet Res 1958; 18: 677-80

12 Kasai K, Kobayashi R. Stomach spirochetes occurring in mammals. F Parasitol 1919; 6: 1

13 Doenges JL. Spirochetes in the gastric glands of mucous rhesus and man without related disease. Arch Pathol 1939 27: 469-77.

14 Lee A, Hazell S. Campylobacter pylori in health and disease an ecological perspective. Microbiol Ecol Health Dis 1988; $1-16$.

15 Lee A, Hazell SL, O'Rourke J, Kouprach S. Isolation of a spiral shaped bacterium from the cat stomach. $\mathrm{Am}$ Soc Microbiol 1988; 56: 2843-50.

16 Heilmann KL, Borchard F, Nowottny U. Gastritis caused by Gastrospirillum hominis. Klin Wochenschr 1989; 67 (suppl Gastros : 27 .

17 Salomon $\mathrm{H}$. Über das Spirillum des Säugetiermagens und sein Verhalten zu den Belegzellen. Centralblatt für Bacteriologi 1896; 19: 433

18 Lee A, Fox JG, Otto G, Murphy JC. Colonization of germ-free rodents with gastric spirilla mimics C. pylori gastritis. Klin Wochenschr 1989; 67: [suppl 18]: 39-40.

19 Lee A. Neglected niches: the microbial ecology of the gastrointestinal tract. In: Marshall KC, et al. Advances in microbia ecology. 8. New York: Plenum, 1985: 115-62.

20 Lee A, Dent J, Hazell S, McNulty CA. Origin of spira organisms in human gastric antrum. Lancet 1988; i: 300 . 